\title{
POSSIBLE INFLUENCE OF FIRE EXTINGUISHERS ON HUMAN'S
} HEALTH

Radoje Jevtić ${ }^{1}$

\section{МОГУЋИ УТИЦАЈ СРЕДСТАВА ЗА ГАШЕЊЕ ПОЖАРА НА ЉУДСКО ЗДРАВЉЕ \\ Радоје Јевтић}

\section{Summary}

Fire protection implies using of many different fire extinguishers that present materials which contacting with combustible materials permanently stop fire and burning process. They are very effective and their fire extinguish methods are different. Some of them are not danger for human's health but some of them can be very danger for human's health in some conditions of their usage, such as $\mathrm{CO}_{2}-$ carbon dioxide, powder, halons and similar.

This paper has written to show some of the main fire extinguishers and their potential danger influence on human's health.

Key words: fire, health, fire extinguishers, humans.

\section{Сажетак}

Заштита од пожара подразумева коришћење многих различитих средстава за гашење пожара који представљају материјале који у контакту са запаљивим материјалом трајно прекидају пожар и процесс горења. Они су веома ефикасни и ьихови начини гашења пожара су различити. Неки од них нису опасни по људско здравље, али неки од њих могу бити веома опасни по људско здравље у неким условима нихове употребе, као што су $\mathrm{CO}_{2}-$ угљендиоксид, прах, халони и слично.

Овај рад је написан да покаже неке од главних средстава за гашење пожара $и$ юихов могући утицај на здравље људи.

Кључне речи: пожар, здравље, апарати за гашење пожара, људи

\footnotetext{
${ }^{1}$ Radoje Jevtić, PhD in technical sciences, School for electrical engineering "Nikola Tesla“, Niš, Srbija (Радоје Јевтић, дипломирани инжењер електротехнике, ЕТШ „Никола Тесла“, Ниш, Србија).
} 


\section{INTRODUCTION}

$\mathrm{B}$ urning process is one of the most complicated processes that man has ever met in his life and work. The answer on that question is not easy and because of that, burning term in different fields of sciences can be differently defined. The limitations of this paper don't allow detail explanations about this term, but, briefly, it can be defined as oxidation process (physics-chemical) - connection process of flammable material and oxygen from air (or some other oxidation means). This connection process releases chemically bounded heat. For physics-chemical burning process, the presence of four elements were needed: presence of flammable material, presence of oxidation mean, presence of adequate fire source and presence of chain reaction.

Not every burning process presents fire but even at the smallest burning that causes material damage or some kind of danger can be characterize as fire. Fire spreading depends from many different factors. In addition, fires can be classified according to the different factors, and one of them is classification according to flammable material class. There are several classes of fires according to this factor. ${ }^{(1)}$

Fire of class $\mathrm{A}$ - this class comprises fires of wood, coil, cotton, flax, paper, straw and similar materials that burning with flame and zeal.

Fire of class B - this class comprises fires of liquid fuels and other flammable liquids that cannot be mix with water (gasoline, petroleum, gas oils, motor liquids and many other).

Fire of class $\mathrm{C}$ - this class comprises fires of burning gasses, such as propane, methane, hydrogen, acetylene and other. They are burning only by flame or immediately - by explosion.

Fire of class D - this class comprises fires of light metals - aluminum, magnesium and their alloys. They can burn with very strong explosion.

Fire of class $\mathrm{E}$ - this class comprises fires at electric equipment up to $1000 \mathrm{~V}$. However, it is important to note, this norm was discarded-early, this norm had been current according to EN2.

Fire of class $\mathrm{F}$ - this class comprises fires of fat and oils of herb or animal origin. Very characteristic property for these fires is their explosion development in reaction with water and self-burning properties.

Unfortunately, there is no universal fire extinguisher that can be used for all types of fires. There are some limitations so it implied the choice of adequate fire extinguisher with the biggest effects. Fire extinguishers are materials that permanently stop burning process when they contact with them. The main fire extinguishers are water, foam, carbon dioxide, hallon, the "new" clean fire extinguishers and hand fire extinguishers. Some of them can be used without any danger influence on human's health, but some of them could have danger influence on human`s health..$^{(2,3)}$

\section{FOA $\boldsymbol{A}$}

Foam presents fire extinguisher consisted from bubbles with emulsion membrane, which interior is filled with carbon dioxide, air or some other gas. According to gas type, foam can be chemical (bubbles are filled with carbon dioxide) or mechanical (bubbles are filled with air). The main "extinguishing targets" for foam are flammable liquids, by smother effect. Foam is the only fire extinguisher that is produced directly at the spot. Foams can be divided on low expansion foams (heavy foams), middle expansion foams (middle foams) and high expansion foams (light foams).

Foams are not proper for fires where flammable materials react with water very turbulent. Foams are also not proper for fuel fires, such as propane, butane and for the electrical devices under voltage. Synthetic foams can destruct human's and animal's food (fires in tanks with eatable oil, oil for frying or cooking and different alimentary articles). Synthetic foam can contaminate drinking water. Low expansion foam shouldn't be used for fires where 
water produces danger chemical reactions (with light metals, for example). Fire extinguishing devices with water and foam (made by SRPS Z.C2.050 or SRPS Z.C2.055 standards) are presented on figure 1 , while vehicle intended for fire extinguishing with water and foam is presented on figure 2 .

Figure 1. Fire extinguishing devices with water and foam (figure source: http://www.vatrosprem. co.rs /protivpozarni-aparati/vatrogasni-aparatiza-gasenje-vodom-i-penom/).

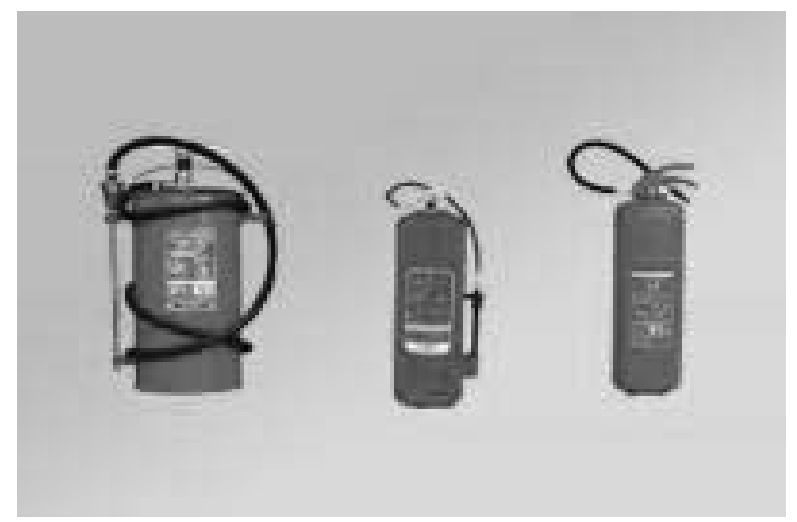

Figure 2. Vehicle for fire extinguishing with water and foam (figure source: http://prezentacije.mup. gov. $r s /$ svs/vozilo2 . $h$ tml).

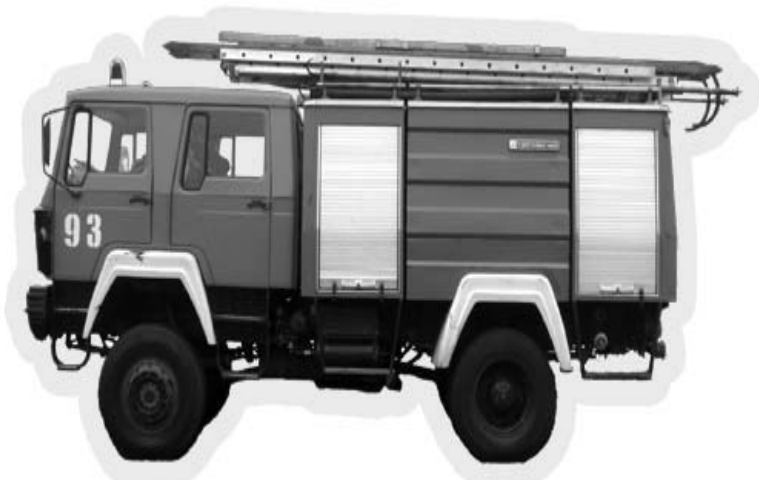

\section{CARBON DIOXIDE}

Carbon dioxide $\left(\mathrm{CO}_{2}\right)$ can be found in nature as free or chemically connected. Their percentage in air is about 0.02 up to $0.003 \%$. Carbon dioxide is heavier than air about 1.5 times. It can be found in every of three aggregate conditions: solid, liquid and gas. It is not poisonous, it does not burn and it does not support burning. It is used for fire extinguishing in handle-transfer devices, special fire vehicles and stable systems. It is used for B, C and E fires, in three forms, as "snow", as fog and as gas. It has full effects only in closed areas. It can be used as fire extinguisher for: storages, electrical installations, flammable liquids, industrial departments, archives, libraries, museums, food storages, medicaments and similar.

Carbon dioxide can be danger for persons in closed areas. For successful extinguishing, the quantity of carbon dioxide must be significantly bigger from carbon dioxide quantity that is safe for organism. At volume density of $4 \%$, persons can fill headache, sounds in ears and slight giddiness. Volume density from $5-6 \%$ is danger for human's life. $8-10 \%$ causes giddiness, while $20 \%$ causes nervous system failure. Volume density of $25 \%$ causes fast death. In case when the gas is thrown out of the bottle, a harmless electrostatic discharge occurs. Some of portable fire extinguishers based on carbon dioxide are presented on figure $3 .^{(4,5,6,8,9)}$

Figure 3. Portable fire extinguishers with carbon dioxide (figure source: https://zezam.jimdo.com/ po sao/pp-aparati/).

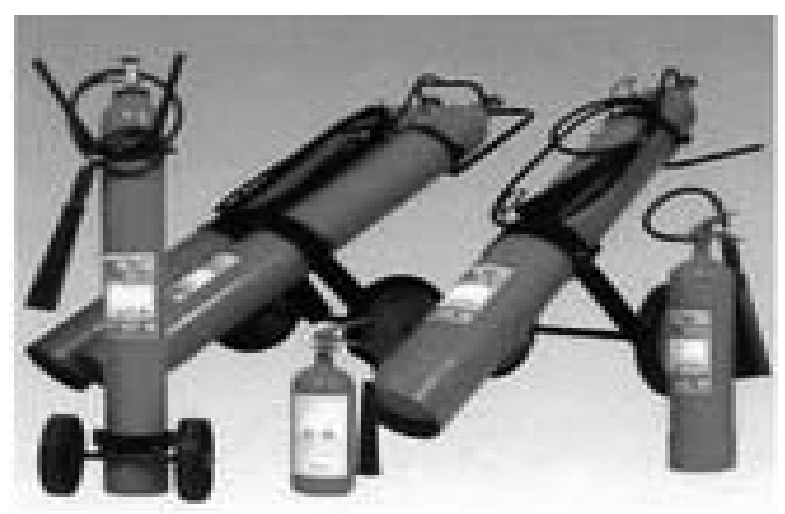

\section{HALONS}

Production, distribution and usage of halons were forbidden by Montreal protocol, in September 1987. The main reason for this is the fact that halons belong to freon's chemical group (fluorine-chlorine-carbon). So, in 1994, almost all of halons production stopped. Many of developed countries had their own banks of halons where halons were collected and recycled. There is no such of institution in Serbia. 
Halons actually present derivatives of carbon and alkanes, where the hydrogen atoms were changed with some of halogen atoms (fluorine, chlorine, bromine and iodide). According to its chemical structure, they exert corrosive activity that increases with humidity increment. Because of practical reasons, the numerical system of halon marking was established. The first number indicates number of $\mathrm{C}$ atoms (carbon), the second number indicates number of $\mathrm{F}$ atoms (fluorine), the third number indicates number of $\mathrm{Cl}$ atoms (chlorine), the fourth number indicates number of $\mathrm{Br}$ atoms (bromine) and the fifth number indicates the number of $\mathrm{J}$ atoms (iodine). The most famous halons are 1211, 1301 and 2402.

In normal ambient conditions, halons present liquids or gases. At high temperatures, the decomposition occurs and the poison gas phosgene $\left(\mathrm{COCl}_{2}\right)$ is relieved. The decomposition products also irritate eyes and respiration ways what leads to lungs destruction. Some of halons can bring to narcotic appearances. The virulence of halons mostly originates from chlorine. When it comes to human's organism it dissolves and sediments in fat tissues. The consequences are irritability, dizziness, qualms, spasms and strong headache. The potential cardiac and central nervous system effects also should be considered. As example, halon 1301 firefighting system is presented on figure $4 .(2,4,5,6,7)$

Figure 4. Halon 1301 firefighting system (figure source: https://chinapingan.en.ecplaza. net/products/ halon-1301-firefightingsystem_242967).

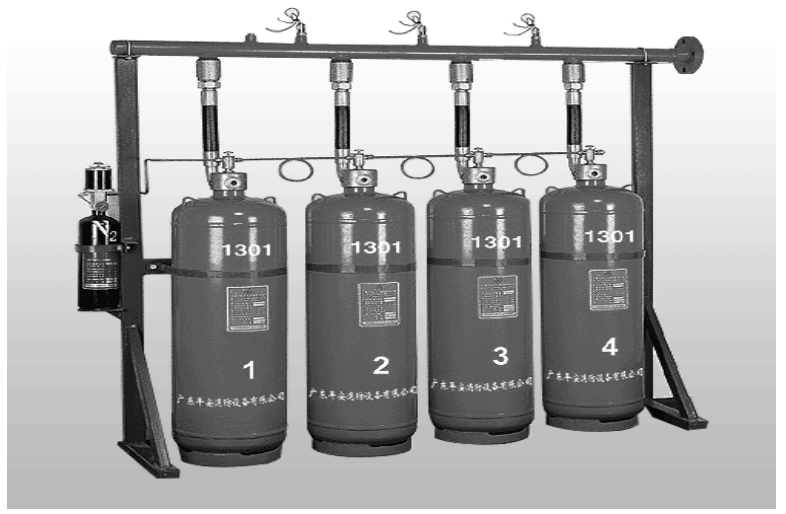

\section{AEROSOLS}

Aerosols are fire extinguishers in form of microscope particles that stop burning process. They originated in Russia. They can be used for A, B and C class of fires and in cases of fires on electrical equipment. They must not be used for fires in rooms with flammable liquids or dust that can produce explosive mixtures. Earlier aerosols were injurious for human's health in sense of coughing and eye's redness. Newer products were classified in class of low danger materials. ${ }^{(2,4)}$

\section{INERT GASSES AND INERGEN AS FIRE EXTINGUISHERS}

Gasses that belong to inert gasses group are nitrogen $(\mathrm{N})$, argon $(\mathrm{Ar})$ and carbon dioxide $\left(\mathrm{CO}_{2}\right)$. They are used for fire extinguishing in closed rooms, storages, on electrical devices, industrial plants, machines ... They also have usage in prevent fire protection from explosion and corrosion. In sense of health risk for human`s health, everything is the same as in case with carbon dioxide. They have no influences on nature and living environment.

Inergen presents mixture consisting of Argon $(50 \%)$, Nitrogen $(42 \%)$ and $\mathrm{CO}_{2}(8 \%)$. It has very good properties according to living environment, ozone layer, people, electronic equipment and has low specific conductivity. At high temperatures, it does not react so it does not have any additional products. It was considered by laboratorial investigations that it does not infect on human's breath organs even in the case when oxygen percentage was lower than $12 \%$. Investigations also showed that people can stay in rooms with inergen up to seven minutes without any consequences for theirs health. An example of inergen fire extinguishers are presented on figure $5 .^{(2.4,5,6,10)}$ 
Figure 5. Inergen fire extinguisher (figure source: http://www.firesuppression.co.uk/inergen.aspx).

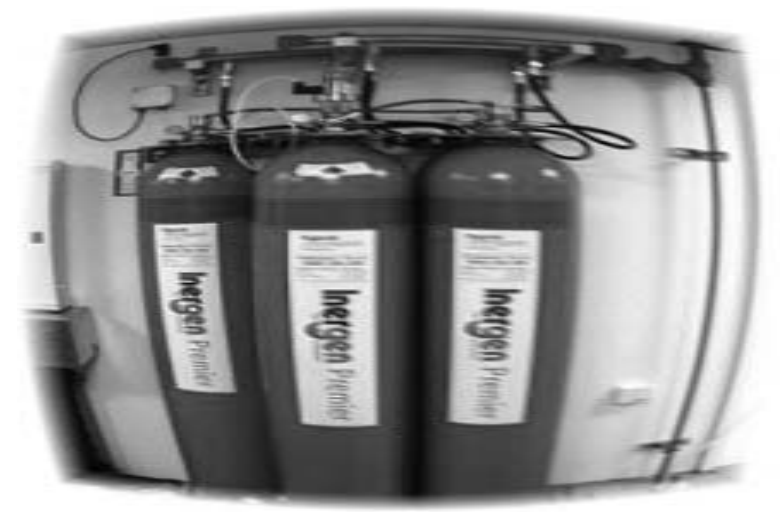

\section{CONCLUSION}

Fire extinguishers are necessary staff to break and stop fire. Many of them have no health consequences on human's health but some of them could be danger in some conditions so it is very important that members of fire brigades and other fire units be prepared, trained and educated to be able to properly assess the state of fire and use the appropriate fire extinguishers. It is very important that fire safety management and protection permanently follow newer and newer solutions, technologies which proper and adequate usage can significantly decrease risk for human's health and increase possibilities for success, effective and safe stopping of fire. ${ }^{(11,12)}$

7. Holness DL, House RA. Health effects of Halon 1301 exposure. J Occup Med. 1992, Jul; 34(7): pp. 722-727.

8. Jevtić BR. Combustion as fire consequence-great danger for humans health. Zdravstvena zaštita, 2015; Vol 6: pp. 55-62, YU ISSN 03050-3208, Belgrade, Serbia.

9. Jevtić BR. The influence of fire consequencies on humans health and its possible elimination. Zdravstvena zaštita, 2014; Vol 3: pp. 53-59, YU ISSN 030503208, Belgrade, Serbia.

10. http://www.virsistem.co.rs/gasenjepozara/gasenje-inertnim-gasovima/

11. Hasofere AM, Beck VR, Bennetts

ID. Risk Analysis in Building Fire Safety Engineering. Elsevier, 2007.

12. Furness A, Mucket M. Introduction to Fire Safety Management. Elsevier, 2007.

Contact: Dr Radoje Jevtić, ETŠ „Nikola Tesla“, Aleksandra Medvedeva 18, 18000 Niš, Srbija, Phone: +381 637590193 ; +381 8028 162, E-mail: milan.jvtc@gmail.com 